\title{
Preparation for and Recovery from Hurricanes and Windstorms for Tropical Fruit Trees in the South Florida Home Landscape 1
}

\section{Jonathan H. Crane and Carlos F. Balerdi ${ }^{2}$}

Well in advance of the hurricane season an assessment of the location and size of the fruit trees in the home landscape should be made. Ideally, fruit trees with a potential to become large (e.g., avocado and mango) and not regularly pruned should be planted $25 \mathrm{ft}$ or more away from the home, other structures (e.g., garage and tool shed), power lines, and other trees. If, however, a large fruit tree is already in-place, a certified arborist should be contacted to reduce tree height and properly prune the tree to open the canopy to wind movement. Alternatively, large, potentially hazardous fruit trees may be transferred to a new location or removed completely and a new fruit tree established at a greater distance from the home, structure, or power lines. Before work begins, check with local county agencies on regulations for pruning and/or removing fruit trees from the home landscape.

The most effective cultural practice to reduce the potential for tree toppling and major damage is

managing tree height and spread. Ideally, fruit trees in the home landscape should be pruned annually or biannually beginning soon after planting to develop a strong tree structure and later to remove dead wood, reduce tree height and spread (if needed occasionally), and open the tree to wind movement. Small fruit trees such as guava and sugar apple may be kept at 3 to $12 \mathrm{ft}$ and 6 to $12 \mathrm{ft}$ high, respectively. Potentially large trees like avocado may be kept at 10 to $15 \mathrm{ft}$ and mango at 6 to $15 \mathrm{ft}$ high with judicious but regular pruning (Table 1 ).

Proper planting of fruit trees will reduce the potential for storm related toppling and uprooting in the future. The deeper and more extensive the lateral root system the less likely the tree will topple, uproot, or lean after a windstorm. Root growth and establishment will be facilitated by loosening a large area of soil during the planting process. In sandy type soils found throughout much of Florida, the planting hole should be 3 times the size of the container the tree came in. In Miami-Dade and Monroe counties where the soil is often a rocky, limestone-based material, augering or excavating large holes or

1. This document is HS1066, one of a series of the Horticultural Sciences Department, Florida Cooperative Extension Service, Institute of Food and Agricultural Sciences, University of Florida. Original publication date April, 2007. Visit the EDIS Web Site at http://edis.ifas.ufl.edu.

2. J. H. Crane, Professor and Tropical Fruit Crops Extension Specialist, Tropical Research and Education Center, Homestead, FL; C.F. Balerdi, Professor and Multi-County Fruit Crops Extension Agent, Miami-Dade County, Homestead, FL; Cooperative Extension Service, Institute of Food and Agricultural Sciences, University of Florida, Gainesville, 32611.

The Institute of Food and Agricultural Sciences (IFAS) is an Equal Opportunity Institution authorized to provide research, educational information and other services only to individuals and institutions that function with non-discrimination with respect to race, creed, color, religion, age, disability, sex, sexual orientation, marital status, national origin, political opinions or affiliations. U.S. Department of Agriculture, Cooperative Extension Service, University of Florida, IFAS, Florida A. \& M. University Cooperative Extension Program, and Boards of County Commissioners Cooperating. Larry Arrington, Dean 
multiple holes is essential in establishing a root system with some ability to anchor trees in place.

Flooding potential before planting is an important factor to consider in south Florida. If there is a possibility of flooding, then consider bedding or mounding the soil, and choose flood-tolerant fruit species.

Tools to have on hand include a lopper, a hand clipper and a hand saw, a pole saw, a shovel, a pick and a digging bar, and, if possible, a chainsaw with extra chains and fuel.

Before a storm, photographs of the landscape may be useful documentation, especially if the landscape is insured. Place a person in the photograph to show the size of the trees before the storm

\section{Post-Hurricane Practices}

\section{Documentation}

Post-storm documentation may be valuable for insurance claims where fruit trees cause damage to the home and the landscape, if the landscape is insured. Take photos of the damage to the home structures and fruit trees and, as with the pre-storm photographs, have someone stand in the pictures to provide scale. Write down the type of damage to each tree, e.g., toppled, wind-thrown, major limb damage, flooded, etc.

\section{Immediate Sun Protection}

Overheating of sun-exposed tree trunks and limbs (commonly called sunburn) is potentially a severe problem encountered when fruit trees are toppled or leaning after a storm. Immediately covering the upper, sun-exposed surface of the tree trunk, major scaffold limbs and exposed roots with detached (fallen) limbs and/or other debris will shade them from sunlight. Alternatively, immediately painting the exposed areas with a 50/50 mixture of white latex paint and water will reflect sunlight and keep the exposed surfaces from overheating due to excessive sun exposure.

\section{Toppled Trees}

Fruit trees that have fallen over but still have some root system in the ground and have leaf canopy remaining can be saved but, are in danger of drying out (drought stress). Pruning to remove some but not all the canopy (maybe 1/3 of what remains) will reduce the water demand of the tree by reducing the water loss from the tree.

\section{Resetting Trees}

Resetting large ( $15 \mathrm{ft}$ tall or greater) trees requires large equipment such as a tractor or backhoe, and may not be feasible for most home owners to do themselves. Hiring a licensed arborist or landscape contractor may be appropriate.

To stand up toppled trees that have part of the root system in the ground, reset the trees back to the same soil level they were before falling. Resetting steps include: a) pull back the soil from the area where the roots came out of the ground so the tree will reset at or near the soil level at which it grew before it toppled; b) remove badly broken roots (but try to leave as many as possible) and any tap roots that prevent the tree from resetting at or near the same soil level as before and; c) cut back the top of the tree (the larger the tree the more you may need to cut in order to reduce the trees top weight) in order to pull the tree up. It may also be appropriate to remove some (not all) canopy to reduce water demand and loss. When using equipment (truck, tractor, or backhoe) to stand a tree upright, use only cloth or rope slings because cable-wire or chain slings damage tree bark, and if they snap, they are very dangerous. Once the tree is standing, place one or more Y-shaped braces against the trunk to steady it. Braces may be made out of limbs pruned off or broken off damaged trees. Finally, after applying water to fill the excavated hole, fill in the reset tree with soil to cover the roots and again soak the root area with plenty of water. This should work for most large fruit trees.

Large trees that remained standing after the windstorm and that have retained some of their leaves may not need to be protected from sun exposure or only parts of the tree may need to be covered or painted. However, even though these trees may have 
only a few broken limbs here and there and may look relatively sound, the root system most likely has been damaged to some extent, and you may begin to see drought stress symptoms, e.g., leaf wilting, fruit drop, stem and limb dieback. We recommend that: a) if the tree has fruit, remove most or all of it and $b$ ) remove $1 / 3$ to $1 / 2$ the canopy to reduce the water demands of the canopy on the reduced root system. In general, trees showing signs of drought stress that have fruit tend to decline and die at a greater rate than those with little or no fruit.

Recommendations for small trees that have fallen over include covering the trunk and major limbs with debris, removing $1 / 3$ to $1 / 2$ of the canopy, and resetting the tree to an upright position as soon as possible. Follow the same procedure for resetting used for large trees. Small trees that have not fallen over and that have retained their leaves and/or fruit should be monitored closely for signs of drought stress, an indication of root and/or trunk damage. As with large trees, it may be prudent to remove some or all of the fruit first and if the tree continues to show signs of further decline, remove some of the canopy.

\section{Flooded Trees}

The tolerance to flooding or saturated soil conditions of tropical and subtropical fruit trees varies (Table 2). Some fruit trees such as avocado and papaya may not withstand more than a day or two of saturated or flooded soil conditions. In contrast, mango trees may withstand several weeks and guava trees a week of saturated or flooded soil conditions.

Symptoms of flooding stress include dead roots, leaf and stem wilting, leaf yellowing and browning, leaf drop, stem and limb dieback, fruit shriveling and/or drop, and tree death. Fruit should be removed from trees with little to no tolerance to saturated soil conditions, and trees showing signs of flooding stress should have up to $1 / 2$ the leafy tree canopy removed to reduce the stress imposed by soil conditions.

Reducing the size of the canopy will improve the chances for tree survival.

\section{Effect of Post-Storm Weather Conditions}

The hurricane and tropical storm season in Florida lasts from June through November. The minimum and optimum temperatures necessary for tree growth of tropical and subtropical fruit trees vary (Table 3), but warm to hot weather with periodic rainfall after early and mid-season windstorms is generally conducive to new shoot and leaf growth and rapid recovery of the tree canopy, whereas cooler temperatures and less frequent rainfall after late-season windstorms, e.g., October through November, result in less canopy recovery and/or nutrient deficient regrowth.

Weather conditions after a late-season hurricane may not provide enough hours above the minimum temperatures required for root, shoot, and leaf growth from November through March (Table 3 and Table 4). Water and nutrient uptake for many tropical/subtropical fruit crops are slowed or inhibited during cool weather thus making tree growth less vigorous and potentially nutrient deficient. Recovery from late windstorms may take 4 to 8 months longer than from early and mid-season windstorms.

\section{Watering}

Trees that remained standing after the storm with most of their canopy intact should be watered regularly (e.g., 2 to 3 times per week) to keep an adequate soil moisture level, especially during prolonged dry periods. Only trees showing drought symptoms should have $1 / 3$ to $1 / 2$ of the canopy removed to reduce tree water loss. For trees that have few to no leaves or that toppled and were reset, reduce watering until new shoots and leaves begin to emerge, and then resume regular watering. Do not over water.

\section{Fertilizing}

Trees that remain standing after a storm with $1 / 3$ or more of the canopy remaining should be fertilized frequently with small amounts of complete (nitrogen, phosphate, potash, magnesium) fertilizers. Once leaves emerge and are about half-grown, foliar micronutrients (zinc, manganese) and soil drenches of chelated iron materials should be made every $2^{\text {nd }}$ or $3^{\text {rd }}$ month until the leaves are full-grown. Once the new growth has matured, fertilize trees normally. 
Trees with few to no leaves or with some of the canopy cut off by pruning should be fertilized with a reduced amount of fertilizer (e.g., if half the leaves are gone, reduce the rate by $50 \%$ ). However, as the new shoots and leaves begin to emerge, use small amounts of fertilizer frequently. Trees that toppled and were reset should only be fertilized with a small amount of fertilizer as new shoots and leaves begin to emerge. Once the new growth has matured, fertilize trees normally.

Tree growth and recovery will be much slower after late season hurricanes or tropical storms. To encourage healthy regrowth more frequent light applications of complete fertilizers, foliar micronutrients, and soil drenches of chelated iron may be necessary.

\section{Insect and Disease Control}

Beetles that bore into the bark of damaged trees may be a problem after a tropical storm or hurricane. Typically trees undergo drought stress after a storm due to root damage. These beetles can sense trees under drought stress and attack the tree. The beetles inoculate the tree with a fungus that then colonizes the tree and kills it. Symptoms of bark boring beetles include small holes along major limbs and or the trunk with frass (excrement that resembles sawdust). Prune off dead or dying branches infested with borers and remove the debris from the landscape. The best remedy is to reduce the potential for tree damage and the chances of water and heat stress on the trees. That means annual pruning to reduce tree size and potential toppling and covering the exposed trunks and limbs of fallen trees as quickly after the storm as possible.

\section{Weed Control}

Due to the loss of tree canopy and the subsequent increase in soil light exposure, weeds may proliferate after a windstorm or hurricane. Weeds should be controlled manually or with approved herbicides to reduce the competition between the recovering tree and weeds for water and nutrients. Do not use residual herbicides because they may cause damage to the trees. Four to 6 inches of mulch applied several inches from the trunk outward to the previous drip-line will assist in suppressing weed growth and help maintain soil moisture. Do not place mulch against the tree trunk. The bark and wood may rot if the mulch touches the tree.

\section{Hurricane Tolerance of Selected Tropical Fruit Trees}

\section{Abiu}

There is very limited experience with abiu, but its hurricane tolerance may be similar to that of mamey sapote and caimito.

\section{Atemoya and sugar apple}

Strong winds generally result in leaning or toppled atemoya and sugar apple trees, and attempts to reset trees to an upright position are frequently unsuccessful. Generally, tree regrowth is slow and nutrient deficient, and trees may decline slowly over a long period of time. Replanting may be a better option if trees begin to decline.

\section{Avocado}

Avocado trees usually reset and recover well from hurricane wind damage and historically have resumed fruit production in 1 to 3 years after a storm. Avocado trees harvested before a storm event generally had less damage than those with fruit. Avocado trees exposed to flooding for more than a day or two generally declined or died.

\section{Banana}

In general, banana plants with fruit topple and the fruit is damaged or lost. However, banana plants recover well from hurricane damage because they regrow new pseudostems from the underground growing points.

\section{Black Sapote}

Black sapote trees tend to reset and recover well from hurricane damage. Fruit production generally resumed 1 to 2 years after a storm.

\section{Cocoa}

Those cocoa plants adjacent to structures for cold protection may be damaged but appear to regrow and resume pod production in 2 to 3 years. 


\section{Coffee}

Coffee plants may be damaged by overhanging trees or limbs that fall. However, coffee plants tend to regrow and resume bean production in 2 to 3 years.

\section{Canistel}

Canistel trees generally reset and recover well from hurricane damage, and fruit production resumed 1 to 2 years after a storm.

\section{Carambola}

Most carambola trees reset and re-grow vigorously after a storm. Historically carambola trees resumed fruit production in 6 to 9 months.

\section{Guava}

Guava trees that were kept small typically remained standing after hurricane wind damage and resumed production in 6 to 9 months. Guava trees that toppled and were reset grew well and resumed fruit production in 1 to 2 years.

\section{Jackfruit}

The results of resetting jackfruit trees after hurricane damage have been mixed; some recover well, others decline slowly. Severe dieback of branches should be expected.

\section{Longan}

Longan trees generally reset well and recover well from hurricane wind damage and resume fruit production in 1 to 3 years. In some cases, regrowth occurs from the roots at the base of the tree, resulting in multiple trunks. Select one strong new shoot and eliminate the rest.

\section{Loquat}

Most loquat trees recover well from hurricane damage and resume fruit production in 1 to 2 years.

\section{Lychee}

The limb structure of 'Mauritius' is weak and brittle, and historically 'Mauritius' lychee trees sustain more limb damage than 'Brewster' trees. Results of resetting have been mixed with some trees regrowing well and resuming fruit production in 1 to 2 years. Trunk splitting to the ground level is common. It causes severe damage and requires tree removal.

\section{Mamey Sapote}

Mamey sapote trees generally reset and re-grow well after hurricane damage. However, those trees with major limb damage may not resume production for 4 to 5 years.

\section{Mamoncillo}

Most mamoncillo trees reset and re-grow well after hurricane damage. However, those trees with major limb damage may not resume production for 5 to 6 years.

\section{Mango}

Resetting toppled mango trees has historically resulted in very mixed results; some trees declined, and others re-grew well. This is because mango trees appear to be highly susceptible to sunburn. Fruit production may not resume for 1 to 3 years.

\section{Pitaya}

Pitaya vines may sustain damage along with the trellis system upon which they grow. Free-standing supports appeared to be more damaged than trellis systems. However, they appear to regrow from those plant parts left after the wind-storm.

\section{Sapodilla}

Sapodilla trees have historically withstood hurricane-force winds well. They usually resume fruit production in 1 to 2 years.

\section{Summary}

Hurricane damage to tropical and subtropical fruit trees in the home landscape may be minimized by annual or bi-annual pruning to reduce tree size and open the canopy to wind movement. Reset trees as soon as possible to reduce the potential for sunburn along the trunk, which results in weak tree regrowth, tree decline, or tree death. Keeping in mind their ultimate size, plant new fruit trees away from buildings, structures, and power lines to minimize 
damage to these structures. When deciding whether or not to reset a tree, base the decision on the size of the tree, and get professionally licensed arborists to handle medium to large trees. Trees exposed to flooding may need some of their canopy removed to increase the chances for tree recovery.

Adjust fertilizer practices when trees are damaged, emphasizing frequent, light applications of all plant nutrients. Adjust watering to the amount of tree damage and the weather conditions. Control insects to reduce further damage to the tree after a storm. Control weeds to prevent competition between the tree and weeds for water and nutrients.

\section{References}

Bartholomew, D.P., R.E. Paull, and K.G. Rohrbach. 2003. The pineapple: botany, production and uses. CABI Publishing, New York, NY. p. 95-96,186.

Lim, T.K. 1991. Abiu. A botanical and agronomic review. Northern Territory Department of Primary Industries and Fisheries Technical Bulletin No. 169.

[http://www2.dpi.qld.gov.au/horticulture/5321.html] (Accessed 14 April 2006).

Malézieux, E., F. Côte, and D.P. Bartholomew. 2003. Crop environment, plant growth, and physiology. In: The pineapple: botany, production and uses. D.P. Bartholomew, R.E. Paull, and K.G. Rohrbach, editors. CABI Pub., New York, NY. P.69-107.

Mejía Ruíz, Danilo and G. Múnera. 1988. El cultivo de pitaya. Esso Agrícola 2:3-12.

Noble, P.S. and E.G. Bobich. 2002. In: Cacti: biology and uses. P.S. Noble editor. Univ. of Calif. Press, Berkeley, CA. p. 57-74.

Núñez-Elisea, R., B. Schaffer, J.H. Crane, and A.M. Colls. 1998. Impact of flooding on Annona Species. Proc. Fla. State Hort. Soc. 111:317-319.

Romney, D.H. 1997. Growing coconuts in south Florida. D.H. Romney Publisher, Homestead, Fla.. p.1-67.
Schaffer, B. and P.C. Andersen. 1994.

Handbook of environmental physiology of fruit crops. Vol. 2: subtropical and tropical crops. CRC Press, Inc., Boca Raton, Fla. p. 1-310.

Schaffer, B. and A.W. Whiley. 2002.

Environmental physiology. In: The avocado: botany, production and uses. Whiley, A.W., B. Schaffer, and B.N. Wolstenholme, editors. CAB Publishing, New York, NY. p. 71-160.

Stover, R.H. and N.W. Simmonds. 1987. Bananas, $3^{\text {rd }}$ edition. John Wiley and Sons, Inc., New York, NY. p. 1-280.

Syvertsen, J.P. and J.J. Lloyd. 1994. Citrus. In: Handbook of environmental physiology of fruit crops. Vol. 2: subtropical and tropical crops. CRC Press, Inc., Boca Raton, Fla. p.65-99.

Verheij, E.W.M. and R.E. Coronel. 1991. Plant resources of South-East Asia ,No. 2: Edible fruits and nuts. Pudoc-DLO, Wageningen, the Netherlands. p. 60-64; 113-114; 152-154; 161-164; 195-198; 258-259; 287-290.

Whiley, A.W. and B. Schaffer. 1997. Stress physiology. In: The mango: botany, production and uses. CAB Publishing, New York, NY. p.147-173; 203-256.

Willson, K.C. 1999. Coffee, cocoa, and tea. CABI Publishing, New York, NY. p. 1-300. 
Preparation for and Recovery from Hurricanes and Windstorms for Tropical Fruit Trees in....

Table 1. Recommended Plant Height for Tropical Fruit Trees Grown in the Home Landscape in Florida.

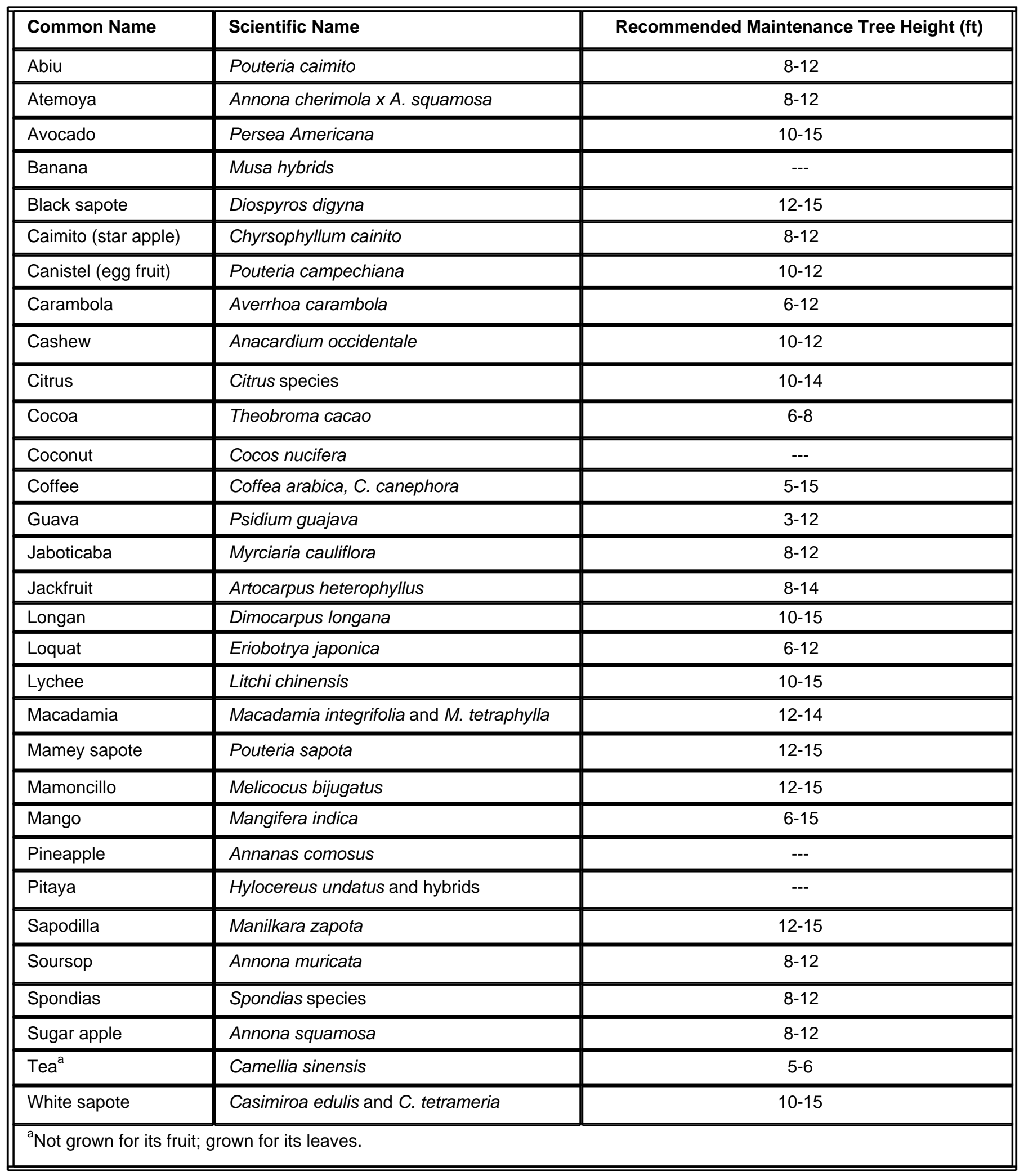


Table 2. Flooding tolerance of selected tropical and subtropical fruit crops in the home landscape.

\begin{tabular}{|c|c|c|}
\hline Tolerant & Moderately tolerant & Not tolerant \\
\hline Caimito & Abiu & Atemoya $^{1}$ \\
\hline Coconut & Banana $^{2}$ & Avocado \\
\hline Grafted citrus $^{1}$ & Canistel & Canistel $^{4}$ \\
\hline Guava & Carambola $^{1}$ & Cashew $^{4}$ \\
\hline Mango $^{5}$ & $\mathrm{Cocoa}^{6}$ & Coffee $^{6}$ \\
\hline Sapodilla & Tahiti Lime & Jaboticaba \\
\hline Spondias species ${ }^{4}$ & Longan $^{1}$ & Jackfruit \\
\hline Soursop $^{7}$ & Lychee $^{1}$ & Loquat $^{4}$ \\
\hline \multirow[t]{8}{*}{ Black sapote $^{4}$} & Macadamia $^{4}$ & Mamey sapote \\
\hline & Mamoncillo & Papaya \\
\hline & & Passion fruit ${ }^{1}$ \\
\hline & & Pineapple \\
\hline & & Pitaya $^{9}$ \\
\hline & & Sugar apple (anon) \\
\hline & & Tea $^{6 z}$ \\
\hline & & White sapote \\
\hline \multicolumn{3}{|c|}{$\begin{array}{l}\text { Sources: }{ }^{1} \text { Syvertsen and Llyod; }{ }^{2} \text { Stover and Simmonds; }{ }^{3} \text { Schaffer and Whiley; }{ }^{4} \text { Verheij and Coronel; }{ }^{5} \text { Whiley et al.; }{ }^{6} \text { Willson; } \\
{ }^{7} \text { Núñez-Elisea et al.; }{ }^{8} \text { Bartholomew; and }{ }^{9} \text { Mejía Ruíz and Múnera. }{ }^{2} \text { Not grown for its fruit; grown for its leaves. }\end{array}$} \\
\hline
\end{tabular}

Table 3. Minimum temperatures for vegetative growth and optimum range of temperatures for growth of selected tropical fruits.

\begin{tabular}{||l|c|c||}
\hline \hline \multirow{2}{*}{ Crop } & \multicolumn{2}{|c||}{ Range in Temperatures ( ${ }^{\circ}$ F) for } \\
Optimum Shoot Growth
\end{tabular}


Table 3. Minimum temperatures for vegetative growth and optimum range of temperatures for growth of selected tropical fruits.

\begin{tabular}{||l|c|c||}
\hline \hline \multirow{2}{*}{ Crop } & \multicolumn{2}{|c||}{ Range in Temperatures ( ${ }^{\circ}$ F) for } \\
Optimum Shoot Growth
\end{tabular}

Table 4. Mean Range and Average Ambient Temperatures from September to August in the Homestead, Florida, Area

\begin{tabular}{||l|c|c||}
\hline \hline Homestead Area $^{z}$ & \multicolumn{2}{|c||}{ Ambient Temperatures ( ${ }^{\circ}$ F) } \\
\hline Month & Range & Average \\
\hline September & $72-89$ & 81 \\
\hline October & $68-86$ & 78 \\
\hline November & $58-78$ & 68 \\
\hline January & $54-76$ & 66 \\
\hline February & $55-77$ & 67 \\
\hline March & $59-81$ & 70 \\
\hline April & $62-84$ & 73 \\
\hline May & $67-87$ & 80 \\
\hline June & $71-89$ & 81 \\
\hline July & $72-90$ & 82 \\
\hline August & $73-90$ & 80 . \\
\hline $\begin{array}{l}\text { Sources: Data from July-Dec., FAWN site Homestead (http://fawn.ifas.ufl.edu/) and the Southeast } \\
\text { Regional Data Center, National Weather Service } \\
\text { (http://cirrus.dnr.state.sc.us/cgi-bin/sercc/cliMAIN.pl?fl4091) 30-year ranges and } \\
\text { averages for Homestead, Fla. (1971-2000). }\end{array}$ \\
\hline
\end{tabular}

